\title{
TREATMENT OF SMUGGLED CIGARETTE TOBACCO AND FOOD SOLID WASTE IN A 2000 L FACULTATIVE REACTOR
}

\author{
Karine Marcondes da Cunha ${ }^{1,2,3, \star}$, Rosimara Zittel ${ }^{1}$, Cleber Pinto da Silva ${ }^{1}$, Gislaine Vieira \\ Damiani ${ }^{2}$, Thainá Aparecida da Silva de Souza ${ }^{2}$, João Vitor Gregório dos Santos ${ }^{2}$ and \\ Sandro Xavier de Campos ${ }^{1}$
}

\author{
${ }^{1}$ Research Group on Environmental and Sanitary Analytical Chemistry (QAAS), Ponta Grossa State University (UEPG), PO Box: 992 , \\ Av. General Carlos Cavalcanti, 4748 Ponta Grossa, PR 84030-900, Brazil \\ ${ }^{2}$ Federal Institute of Paraná, Biotechnology Sciences Department, CEP 82530-230 Jaguariaíva, PR, Brazil \\ ${ }^{3}$ Federal Institute of Santa Catarina, Food Sciences Department, Av. dos Expedicionários, 2150, Canoinhas, SC, 89460-000, Brazil
}

Article Info:
Received:
10 July 2018
Revised:
12 September 2018
Accepted:
19 September 2018
Available online:
13 November 2018
Keywords:
Reactor composting
Facultative reactor
Food solid waste
Smuggled cigarette tobacco
treatment
C/N ratio
Humidified compound

\section{INTRODUCTION}

The accumulation of solid residues due to the growth of urban populations has become evident. Globally, $46 \%$ of the volume of solid organic solid waste generated is sent to landfills, and this increases to $51 \%$ in Brazil, according to the Institute of Applied Economic Research at Brazil IPEA (2012). The disposal of this kind of waste in landfills or dumps entails the waste of nutrients and organic matter that in the natural cycle have the role of fertilizing and maintaining soil life (Abreu, 2017).

In recent years a residue that has been gaining attention in Brazil is the residue from the seizures of smuggled cigarettes. Data from the Brazilian Internal Revenue Service report that approximately $70 \%$ of smuggled goods entering in Brazil are cigarettes (Pegoraro, 2016). Currently, cigarettes seized by the IRS are destroyed by incineration. Such destination uses a large amount of energy and still releases polluting gases such as carbon dioxide, nitrogen oxides, dioxins, among others (Yang et al., 2016). Domes- tic organic waste (DOW) and smuggled cigarette tobacco (SCT) have the advantage that they can be recycled through composting (Abreu, 2017).

Windrow composting is the most common form of composting, and at all scales it has been extensively developed and evaluated, with numerous reports in the literature (Campos et al., 2014). Recent research has demonstrated success in the cigarette tobacco composting process in a reactor, which is an efficient technology to reduce tobacco toxicity and produce matured compost (Kopcic et al., 2014; Zittel et al., 2018).

Different models of reactors were developed and adapted for the treatment of different organic residues as vertical and horizontal, aerobic, anaerobic and facultative (Karnchanawong; Suriyanon, 2011; Kopcic et al., 2014; Jeonga et al., 2017; Zittel et al., 2018). Reactors are systems that usually protect the composting process from environmental factors such as humidity and temperature. Research has evidenced that these biodegradation pro- 
cesses are efficient, using reactors systems in pilot and domestic scales, with forced and natural aeration system (Karnchanawong; Suriyanon, 2011; Jeonga et al., 2017; Zittel et al., 2018).

The facultative reactor is considered a promising technology when compared to conventional techniques. Facultative reactors have two-microorganism phases in mutualism life, the aerobic phase at the top, and the anaerobic phase at the bottom, bringing great advantages to the process (Campos et al., 2017). The treatment does not require the composting compound to be stirred and provides sufficient ventilation for the process, it does not produce unpleasant odors, leaching or even the formation of pollutants. In addition, it provides physical-chemical parameter control and can be used in different weather conditions (Campos et al., 2017; Zittel et al., 2018). Studies about stability and maturity of composts produced by physicochemical analyzes (temperature, humidity, $\mathrm{pH}, \mathrm{C} / \mathrm{N}$ ratio) associated with spectroscopic techniques (FTIR and UV-Vis) have been demonstrated that this process is efficient. In addition, the quality of the final compost can be verified through germination index (GI), concentration of heavy metals and pathogenic microorganisms (Campos et al., 2017).

Researchers have shown that DOW and SCT composting in $200 \mathrm{~L}$ volume facultative reactors from different initial $\mathrm{C} / \mathrm{N}$ ratios yielded matured, stabilized and non-toxic composts (Zittel et al., 2018). The initial $\mathrm{C} / \mathrm{N}$ ratio is an important point for the composting process, since these elements are sources of nutrients for decomposing microorganisms, which throughout the composting process tend to reduce. Recent studies have indicated that the initial $\mathrm{C} / \mathrm{N}$ ratio is dependent on the chemical and physical properties of the residues used and have shown that studies with different initial ratios can contribute to the verification of the efficiency of the process in the treatment of a larger quantity of residue with higher toxic power (Silva et al., 2014).

Studies on reactor composting have been developed from a technical and scientific point of view for pilot and domestic scales, but no investigations were found in the literature presenting facultative reactors with different configurations for the treatment of larger volumes of waste.

Therefore, this search investigated the use of a 2000 $\mathrm{L}$ facultative reactor for the treatment of DOW and SCT. In addition, we attempted to verify the influence of different initial $\mathrm{C} / \mathrm{N}$ ratios. It evaluated the degradation of the residues obtained by physicochemical and spectroscopic techniques and the compost quality using GI, microbiological test and metal concentration.

\subsection{Nomenclature list}

$\begin{array}{ll}\text { DOW } & \text { Domestic Organic Waste } \\ \text { FTIR } & \text { Fourrier Transformation Infra Red } \\ \text { GI } & \text { Germination Index } \\ \text { IR } & \text { Infrared } \\ \text { R1 } & \text { Reactor 1 } \\ \text { R2 } & \text { Reactor 2 } \\ \text { SCT } & \text { Smuggled Cigarette Tobacco } \\ \text { UV-Vis } & \text { Ultraviolet- Visible } \\ \text { WC } & \text { Wood Chips }\end{array}$

\section{MATERIALS AND METHODS}

\subsection{Assembling facultative reactors}

The reactor presents a passive ventilation system on the top, which is responsible for the aerobic phase gaseous exchange (top microbial phase), the anaerobic phase occurs naturally as a result of the compaction due to the weight of the top phase, reducing the flow of gases.

The reactor also has a slurry draining system, with a filter and a tap in its base. Figure 1 shows the details of the facultative reactor designed in real scale.

\subsection{Experiments}

Two reactors were assembled. Reactor 1(R1) was loaded with DOW $(64 \mathrm{~kg})$ which was homogenized by cutting

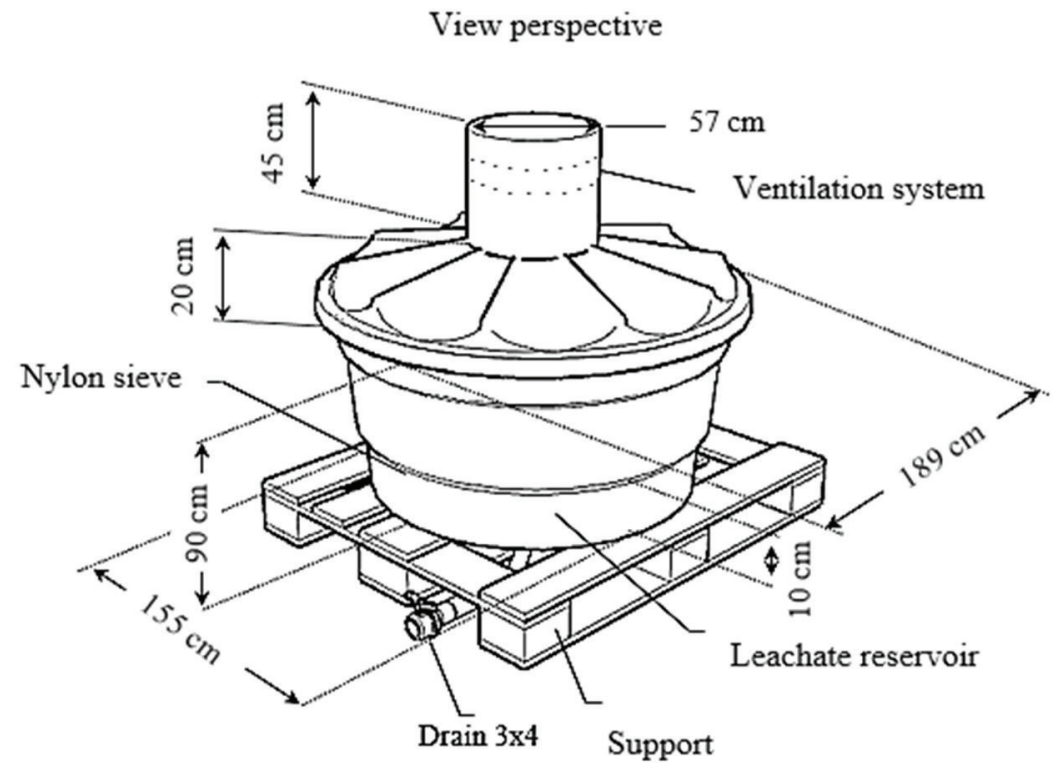

FIGURE 1: 2000 L facultative reactor. 
the material into pieces, approximately $8-10 \mathrm{~cm}$ long, and mixed with WC wood chips (168 kg) into pieces of about 1-3 $\mathrm{cm}$ and SCT (64 kg).

Reactor 2 (R2) was loaded with DOW (120 kg) which was homogenized by cutting the material into pieces, approximately $8-10 \mathrm{~cm}$ long, and mixed with WC $(120 \mathrm{~kg})$ in pieces of about $1-3 \mathrm{~cm}$ and SCT $(120 \mathrm{~kg})$.

The influence of two different $\mathrm{C} / \mathrm{N}$ ratios was investigated with different proportion residues of reactors started the process $\mathrm{C} / \mathrm{N}$ ratio different, with $\mathrm{R} 1 \mathrm{C} / \mathrm{N}$ ratio 28 and $\mathrm{R} 2$ $\mathrm{C} / \mathrm{N}$ ratio 21 The mixture was homogenized and analyzed in several stages for the essential parameters (temperature, $\mathrm{pH}, \mathrm{C} / \mathrm{N}$ ratio, moisture content).

The proposal was to have a reactor working in hypoxic conditions, with top and bottom in mutualism. The top would contribute by capturing odors, if its layers were aerobic. Compounds and also to accelerate the compost stability via nitrification of the system (Campos et al., 2017).

\subsection{Temperature, moisture, $\mathrm{pH}$ and $\mathrm{C} / \mathrm{N}$ ratio}

Temperature analyzes were performed daily, the analysis of $\mathrm{pH}$, and moisture were carried out according to Fialho et al. (2010). The elemental chemical analysis to determine the $\mathrm{C} / \mathrm{N}$ ratio used a TruSpec $\mathrm{CN}$ Analyzer (LECO ${ }^{\circledR}$ brand, St. Joseph, Mi, USA). During each collection, about $100 \mathrm{~g}$ of sample was collected from different points at the top and bottom of the reactor. These samples were homogenized and $20 \mathrm{~g}$ was used for analysis.

\subsection{UV/Vis spectroscopy}

The analyses were performed with samples of the composting process at $01,30,60,90$ and 120 days according to the modified method described by (Sellami et al., 2008). Were $10 \mathrm{mg}$ of dry, comminuted compound was dissolved in $25 \mathrm{~mL}$ of $0.5 \mathrm{~mol} . \mathrm{L}^{-1}$ sodium hydroxide $(\mathrm{NaOH})$ solution. The mixture was stirred for 1 hour and then centrifuged ( 7 min at $7000 \mathrm{rpm})$. The supernatant was diluted 2:1 and the $\mathrm{pH}$ of the solutions adjusted to a range from 8.3 to 8.6 with 2 mol. $\mathrm{L}^{-1} \mathrm{HCl}$ solution. UV-Vis absorption readings, wavelength $200 \mathrm{~nm}$ to $800 \mathrm{~nm}$ (were performed on the Varian Cary $50 \mathrm{BIO} \AA$ apparatus). The $\mathrm{E}_{4} / \mathrm{E}_{6}$ ratio was determined by the absorbance ratio in the range from $465 \mathrm{~nm}$ to 665 nm (Chen; Senesi; Schnitzer, 1977).

\subsection{IR spectroscopy FTIR}

The FTIR analyzes were performed with samples at 01 , $30,60,90$ and 120 days of process according to the method described by (Campos et al., 2017), using a spectrophotometer (brand Shimadzu ${ }^{\circledR}$, model IR PRESTIGE 21). The spectra were obtained in the range from $400 \mathrm{~cm}^{-1}$ to 4000 $\mathrm{cm}^{-1}$ from pellets prepared with $1.0 \mathrm{mg}$ dry sample and 100 $\mathrm{mg} \mathrm{KBr}$.

\subsection{Germination Index (IG)}

For the germination test, the extraction was performed from the dissolution of the compost in distilled water and stirring for $30 \mathrm{~min}$. After filtration in a qualitative filter paper, $5 \mathrm{~mL}$ of the extract was placed on petri dishes with filter paper and the seeds of Lepidium sativum (water cress) were added (Zittel et al., 2018). The incubation took place in a darkroom for 120 hours at $26^{\circ} \mathrm{C}$. After this period, the number of germinated seeds and the root size were measured. The GI was calculated on the basis of eq. 1 .

$G I(\%)=\frac{\text { seed germination of treatment }(\%)-\text { root length treatment }}{\text { seed germination of control }(\%)-\text { root lenght of control }} \times 100$

\subsection{Determination of metals in the final compost}

The total concentration of the metals nickel (Ni), cobalt (Co), cadmium (Cd), chrome (Cr), lead (Pb), copper (Cu), zinc $(\mathrm{Zn})$ and manganese $(\mathrm{Mn})$ in the final compost was determined. The digestion process was carried out according to the method 3050B, United States Environmental Protection Agency US.EPA (1996), using a flame atomic absorption spectrometer - FAAS (brand Varian, model 240 FS).

\subsection{Pathogenic microorganisms}

For the analysis of the presence of Salmonella spp., 10 g. of the sample was diluted in $10 \mathrm{~mL}$ of sterilized water, the solution was seeded with SS agar (Salmonella Shiguella) and incubated in a bacteriological oven at $36^{\circ} \mathrm{C}$ for 24 h. Black colonies indicate that the sample is contaminated with Salmonella spp., method proposed by the National Sanitary Surveillance Agency/Brazil ANVISA (2004).

Coliforms were analyzed according to the method proposed by the FDA - Food and Drug Administration, bacteriological and analytical manual. The samples were diluted in $5 \%$ saline solution, $10^{-1}, 10^{-2}$ and $10^{-3}$, and analyzed using the multiple tube technique (Feng et al., 2002).

Analyses of helminth viable eggs were carried out by the method of Hoffman et al (1934). The technique consists in dissolving about $10 \mathrm{~g}$ of compound in $10 \mathrm{ml}$ of sterilized $\mathrm{H}_{2} \mathrm{O}$. It was filtered in gauze folded in four using a sedimentation cup. The beaker was filled with water and homogenized with a glass rod and allowed to stand for 24 hours.

With a Pasteur pipette, a sample was taken from the bottom of the vessel and the material was deposited on a glass slide with one drop of lugol solution covered with coverslip and examined under a 10x and 40x fold magnification optical microscope to investigate the presence of viable eggs.

\section{RESULTS}

\subsection{Moisture, temperature, $\mathrm{pH}$ and $\mathrm{C} / \mathrm{N}$ ratio}

Regarding $\mathrm{pH}, \mathrm{R} 1$ showed a variation from 5.0 to 6.9 on the first few days of the process and rose gradually up to 9.0 at the end of the 120 days. $\mathrm{R} 2$ started the process at $\mathrm{pH}$ 5.5 , the top part had a gradual increase up to $\mathrm{pH} 8.7$ while the lower part showed acidification at 4.9 in 15 days of the beginning of the process and then a gradual increase up to 8.8 in 120 days.

The temperature was monitored in the top and bottom regions of the reactors for a period of 120 days, as shown in Figure 2. Both had similar behavior.

After the 60-day period, the top and bottom parts showed similar behavior until reaching the ambient temperature in 120 days, revealing decrease in the microbial activity throughout the process. 
Different initial $\mathrm{C} / \mathrm{N}$ ratios for the reactors were evaluated. The initial ratio $\mathrm{C} / \mathrm{N}$ in $\mathrm{R} 1$ was 28 and for $\mathrm{R} 2$ the initial $\mathrm{C} / \mathrm{N}$ ratio was 21 .

This work showed through the results of the spectroscopic analyzes that both initial $\mathrm{C} / \mathrm{N}$ ratios evaluated presented the formation of matured and stabilized humic substances. The physicochemical analyses demonstrated that the stability of the microbial load responsible for the biodegradation of the organic matter was reached. The two ratios used had favorable results for biodegradation.

\subsection{UV/Vis spectroscopy}

The UV/Vis spectroscopic technique made it possible to obtain correlated data with aromaticity and also provided information of the molecular structure of the humic substances obtained after the composting processes $(\mathrm{He}$ et al., 2013).

Figure 3 shows the $E_{4} / E_{6}$ ratios obtained for $R 1$ and $R 2$.

Figure 3 reveals that during the composting process the $E_{4} / E_{6}$ ratios presented variations in their values due to the degradation of the organic matter and the formation of more condensed clusters. After 90 days of processing, these ratios were seen to decrease to values close to 5 , indicating the formation of humified compounds. These results coincided with the temperature stability and conse- quent decrease in the activity of the decomposers microorganisms.

\subsection{IR spectroscopy - FTIR}

The FTIR spectra of the compound samples of the two reactors at different stages of the process are shown in Figure 4 and Figure 5.

No significant difference was observed between the FTIR spectra of the top and bottom regions of the reactors. There was a difference in the spectrum during the composting time.

The spectra of Figures 3 and 4 showed that they presented broadband in the $3450-3270 \mathrm{~cm}^{-1}$ band, referring to $\mathrm{O}-\mathrm{H}, \mathrm{N}-\mathrm{H}$ of alcohols, phenols and organic acids; 2924 $2926 \mathrm{~cm}^{-1}$, indicating the presence of aliphatic groups $\mathrm{C}-\mathrm{H}$ $\left(\mathrm{CH}_{2}, \mathrm{CH}_{3}\right) ; 1650-1660 \mathrm{~cm}^{-1} \mathrm{C}=\mathrm{C}$ aromatic rings and $\mathrm{C}=0$; $1519-1510 \mathrm{~cm}^{-1}$, indicating the presence of $\mathrm{C}=\mathrm{C}$ of aromatic groups, quinones attached to carboxyl and ketones, 1420 - $1410 \mathrm{~cm}^{-1}, \mathrm{C}-\mathrm{O}, \mathrm{C}-\mathrm{O}-\mathrm{H}$; carboxyl groups and 1060$1030 \mathrm{~cm}^{-1} \mathrm{C}-\mathrm{O}$ polysaccharides (Fels et al., 2014; Campos et al., 2017).

\subsection{Germination Index GI}

$\mathrm{GI}$ is used as a mature compound indicator because it is a direct phytotoxicity meter of the compost produced on
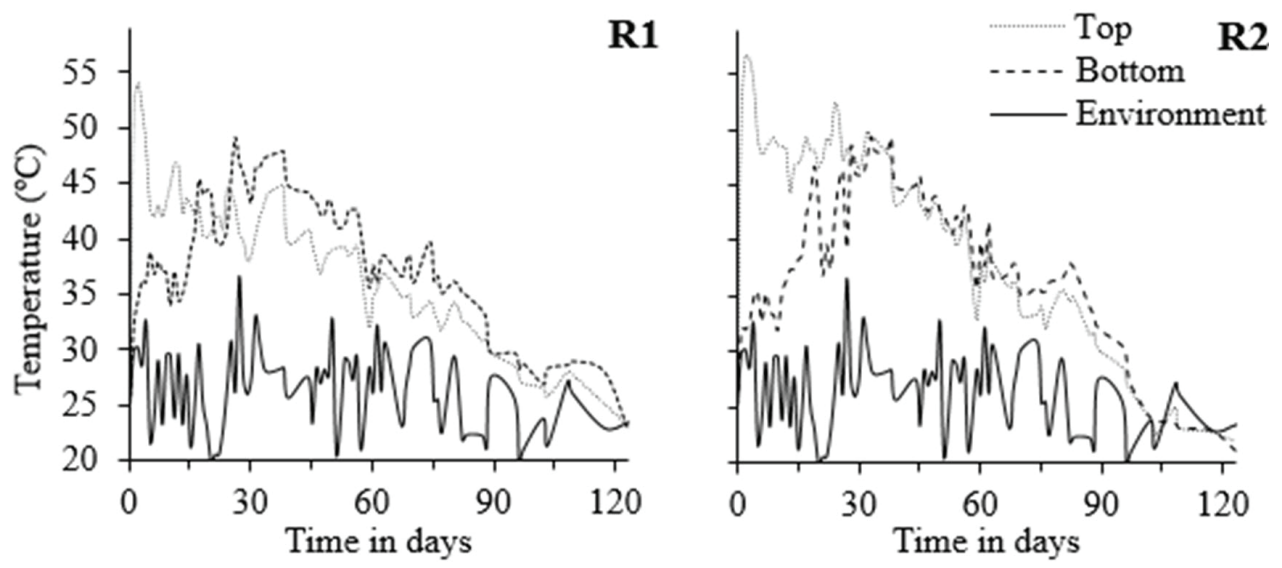

FIGURE 2: Reactors temperature during the composting process.
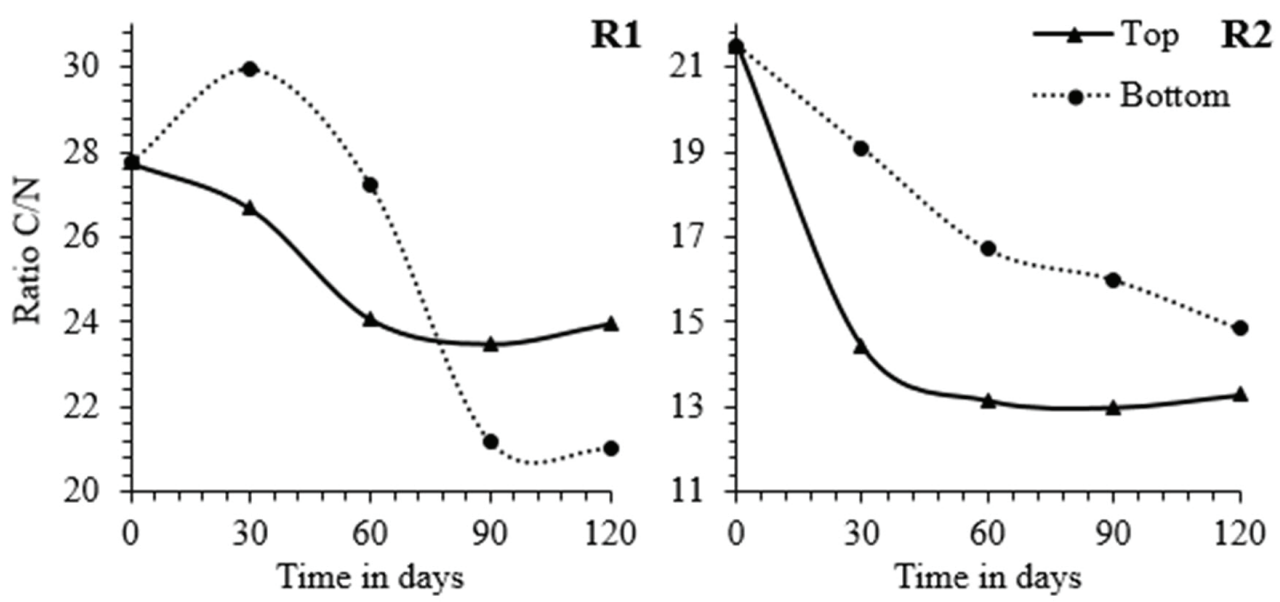

FIGURE 3: R1 and R2 ratio E4/E6; top and bottom. 

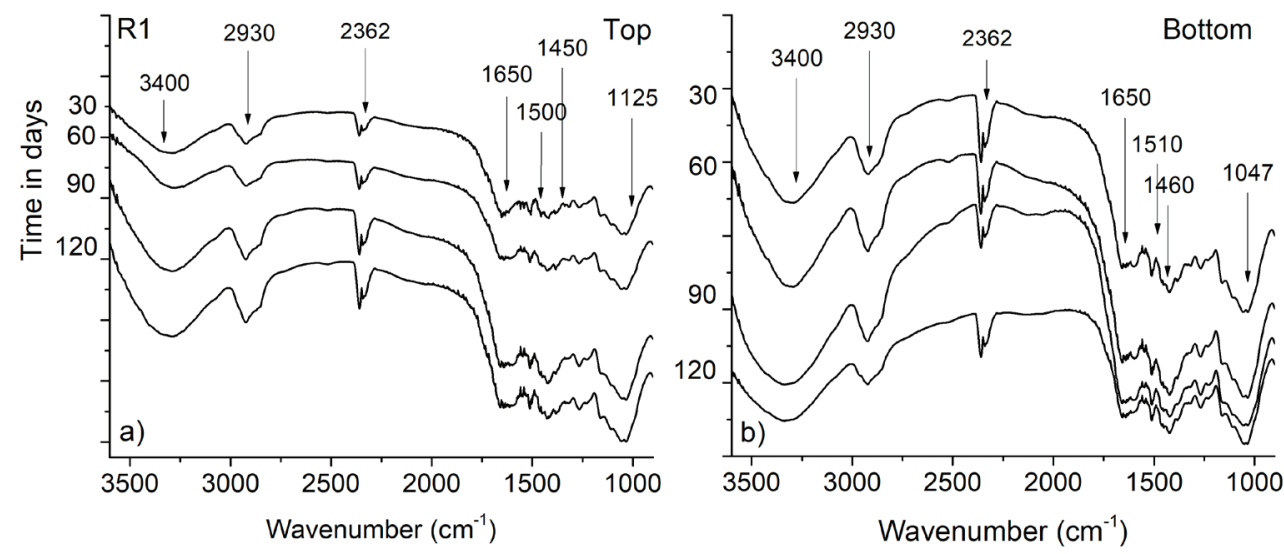

FIGURE 4: FTIR spectrum of the reactor 1.
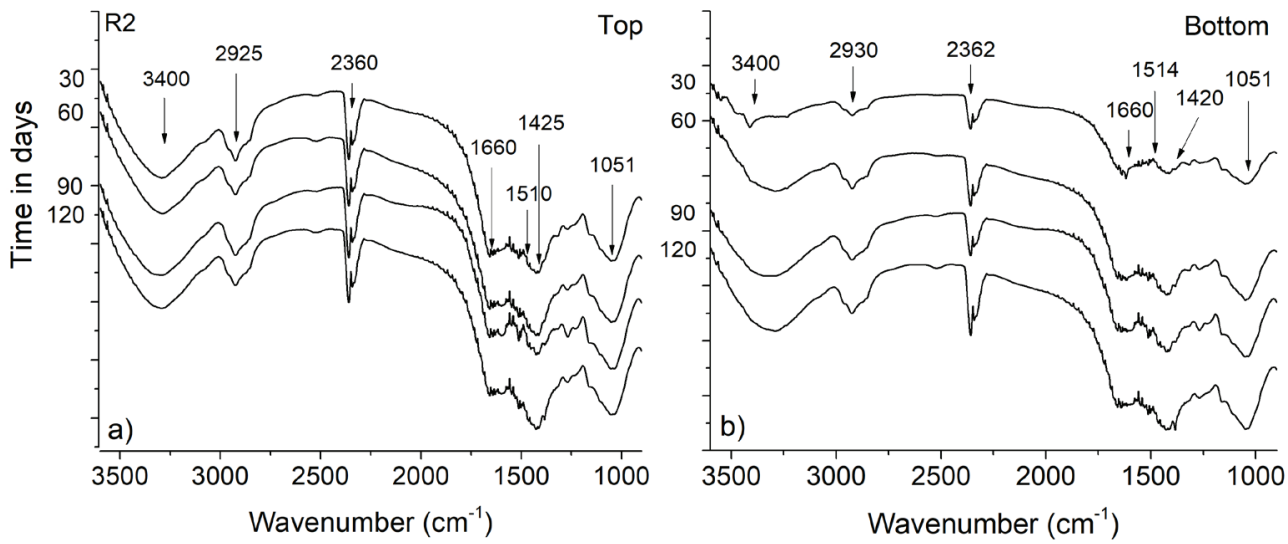

FIGURE 5: FTIR spectrum of the reactor 2.

seed germination (Wang et al., 2017b). For some authors, GI above 80 indicates a mature compost, free of phytotoxicity (Belo, 2011; Guo et al., 2012; Yang et al., 2016; Wang et al., 2017a).

In the composting process studied, R1 obtained GI results of approximately 80 in 90 days the process which was kept up to day 120 . In 90 days of the process R2 showed GI close to 50 , and reached the GI result 82 in 120 days.

\subsection{Heavy metals}

Table 1 presents the results of the metal analyzes in the final compost of the reactors.

Table 1 shows that the metal concentrations in the final compost of reactors 1 and 2 were lower than the maximum limits for heavy metals defined by the agencies - CCME Guidelines for Compost Quality 2005 and USDA Report and recommendation on organic farming 1999 Department of Agriculture.

\subsection{Pathogenic microorganisms}

Table 2 shows results of the microbiological analyses in relation to pathogens of reactors 1 and 2 .

Table 2 shows that the analyses of the reactors revealed absence of salmonella and helminths viable eggs of and the result of thermotolerant coliforms in R1 was $<3$ and while R2 presented 23MLN/g.

The table also provides the maximum limit of contaminants required by the legislations, according to the Ministry of Agriculture, Livestock and Supply/ Brazil MAPA (2014), CCME (2005) and US.EPA (2003).

The final compost analyzed is in accordance with the required microbiological quality standard for MAPA (2014), CCME (2005) and US.EPA (2003), identified in Table 2, providing adequate final compost for pathogenic contaminants.

\section{DISCUSSION}

\subsection{Moisture, temperature, $\mathrm{pH}$ and $\mathrm{C} / \mathrm{N}$ ratio}

Moisture is an important parameter to be evaluated in composting, as it ensures an adequate environment for the microbial development of the decompose. The initial moisture in the two reactors evaluated was close to $70 \%$ and at the end of the process the humidity reached approximately $40 \%$.

Moisture above $70 \%$ hinders the gas exchange in the composting environment and below $40 \%$ prevents the microbial growth responsible for the degradation of organic matter (Richard et al., 2002; Khalid et al., 2011; Campos et al., 2017). In both reactors the evaluated moisture content was suitable for the development of decomposing 
TABLE 1: Heavy metal concentrations in R1 e R2 and maximum limits allowed.

\begin{tabular}{|c|c|c|c|c|}
\hline & $\begin{array}{c}\mathbf{R 1} \\
\left(\mathrm{mg} \mathrm{kg}^{-1} \pm \mathrm{SD}\right)\end{array}$ & $\begin{array}{c}\mathrm{R2} \\
\left(\mathrm{mg} \mathrm{kg}^{-1} \pm \mathrm{SD}\right)\end{array}$ & $\begin{array}{c}\text { USDA } \\
\left(\mathrm{mg} \mathrm{kg}^{-1} \pm \mathrm{SD}\right)\end{array}$ & $\begin{array}{c}\text { CCME } \\
\left(\mathrm{mg} \mathrm{kg}^{-1} \pm \mathrm{SD}\right)\end{array}$ \\
\hline $\mathrm{Cu}$ & $16.4 \pm 1.2$ & $20.5 \pm 0.7$ & 1000.0 & 400.0 \\
\hline $\mathrm{Mn}$ & $285.4 \pm 11.3$ & $359.7 \pm 9.8$ & - & - \\
\hline $\mathrm{Fe}$ & $775.0 \pm 68.9$ & $790.5 \pm 72.8$ & - & - \\
\hline $\mathrm{Ni}$ & $9.2 \pm 1.2$ & $13.6 \pm 1.8$ & 200.0 & 62.0 \\
\hline $\mathrm{Cd}$ & $2.1 \pm 0.1$ & $1.9 \pm 0.1$ & 10.0 & 3.0 \\
\hline $\mathrm{Pb}$ & $9.1 \pm 0.6$ & $9.7 \pm 0.3$ & 250.0 & 150.0 \\
\hline $\mathrm{Cr}$ & $<\mathrm{LQ}$ & $<L Q$ & 1000.0 & 210.0 \\
\hline $\mathrm{Zn}$ & $35.7 \pm 2.2$ & $56.8 \pm 7.4$ & 2500.0 & 700.0 \\
\hline
\end{tabular}

$S D$ - standard deviation; CCME - Guidelines for Compost Quality, Canada (2005); USDA - American Department of Agriculture. Limit of metals in the composts produced by aerobic digestion (1999).

TABLE 2: Concentration of pathogens in R1 and R2 and maximum limits allowed.

\begin{tabular}{|c|c|c|c|c|c|}
\hline & R1 & R2 & $\begin{array}{l}\text { MAPA } \\
(2014)\end{array}$ & $\begin{array}{l}\text { CCME } \\
(2005)\end{array}$ & $\begin{array}{l}\text { US.EPA } \\
(2003)\end{array}$ \\
\hline $\begin{array}{l}\text { Thermo-tolerant } \\
\text { coliforms } \\
\text { (MLN/1g DM) }\end{array}$ & $<3$ & 23 & 1000 & 1000 & 1000 \\
\hline $\begin{array}{l}\text { Salmonella spp. } \\
\text { (MLN/10g DM) }\end{array}$ & $<1$ & $<1$ & $<1$ & $<1$ & $<1$ \\
\hline $\begin{array}{l}\text { Helmints viable } \\
\text { eggs } \\
\text { (MLN/4g of TS) }\end{array}$ & $<1$ & $<1$ & 1 & 1 & 1 \\
\hline
\end{tabular}

$M L N=$ most likely number; $D M=$ dry matter; $T S=$ total solids

microorganisms.

Studies in aerobic, anaerobic and facultative reactors found that $\mathrm{pH}$ decreases during the first weeks of composting due to the formation of organic acids (amino acids and other volatile fatty acids). After this period, neutral $\mathrm{pH}$ values are reached due to the conversion of these acids into carbon dioxide by the action of microorganisms (lyengar; Bhave, 2006; Campos et al., 2017; Razaa, Munirb, Nazb, Ahmedb, \& Ameen, 2017; Zittel et al., 2018)

The evaluation of composts with TCC in reactors showed that an increase in $\mathrm{pH}$ might occur due to the evolution of the ammonia and loss of nitrogen of the substrate. In view of this, the matured compost can promote the immobilization of nitrogen in the soil, reducing $\mathrm{NH}_{4}^{+}$and increasing $\mathrm{NO}_{2}$ and $\mathrm{NO}_{3}$, useful compounds as plant nutrients (Kopcic et al. 2014, Oviedo-Ocaña et al., 2015; Zittel et al., 2018).

Temperature around $40-60^{\circ} \mathrm{C}$ indicates that the ecosystem is well balanced and the microbiological activity will favor the degradation of organic matter (Xie et al., 2016).

The temperature can also be affected by the process porosity (Chowdhury et al., 2014). As the bottom supports the entire weight of the compost above it, the process then takes place under lower porosity and higher compaction. At the bottom of the reactor there is no such natural exchange of gases and, in addition, there is natural compression by the top mass (Zittel et al., 2018).

The time/temperature relationship is closely linked to the inhibition or growth of pathogenic microorganisms (Jones; Martin, 2003; Campos et al., 2017). For elimination of pathogens the temperature should remain above $40^{\circ} \mathrm{C}$ for a minimum of 5 days, during which time the temperature exceeds $55^{\circ} \mathrm{C}$ for at least 4 hours US.EPA (2003). In both reactors the temperatures defined as appropriate for pathogen elimination were reached

The carbon present in the waste is used by the microorganisms as a source of energy and nitrogen is used for cell synthesis. There is consensus in the literature that the ideal $\mathrm{C} / \mathrm{N}$ ratio is between 25/1 and 30/1(Wu et al., 2015). However, lower initial $\mathrm{C} / \mathrm{N}$ ratios mean treating larger amounts of pollutant residues.

Studies show that the initial $\mathrm{C} / \mathrm{N}$ ratio depends on the compost residue, it is possible to start the composting process with ratios below 20 and to obtain a stabilized and matured humified compost (Yen; Brune, 2007; Silva et al., 2014; Wu et al., 2015)

\subsection{UV/Vis spectroscopy}

In the analysis of the initial and final values of the ratio for samples from reactors 1 and 2, there was a decrease in the ratio with the increase in time of the composting process. This decrease in ratio may have occurred due to the mineralization of carbohydrates and quinones, oxidation of phenolic compounds and the presence of methoxy groups and/or aliphatic side chains attached to the humic substances (Sellami et al., 2008).

The $E_{4} / E_{6}$ ratio is inversely proportional to the degree of condensation of the carbon-carbon condensation structures, so that high $E_{4} / E_{6}$ values indicate a low degree of condensation of carbon-carbon instabilities and the presence of various aliphatic structures. Values below 5 for $E_{4} /$ $\mathrm{E}_{6}$ reflect a high degradation and formation of condensed aromatic chains, demonstrating a high degree of humification of the organic matter (Campos et al., 2017; Campos; Ressetti e Zittel, 2014).

The relationship $E_{4} / E_{6}$ has so far been scarcely used to evaluate composting processes in reactors. In this study, the results indicated that composting in the $2000 \mathrm{~L}$ facultative reactor produced final composts with a high degree of humic acids present in the structures of humic substances.

\subsection{IR spectroscopy - FTIR}

The spectra exhibited absorbance in similar regions, however, they differed in the intensity of some peaks, observing the decrease in peaks in the region of $2920 \mathrm{~cm}^{-1}$ and $1100 \mathrm{~cm}^{-1}$, indicating the biodegradation of aliphatic groups (Ouaqoudi et al., 2014).

The peak near $2315 \mathrm{~cm}^{-1}$ occurred because of the $\mathrm{CO}_{2}$ trapped in the $\mathrm{KBr}$ matrix (used in the pellets for the IR analysis), apparently from the decarboxylation of the $\mathrm{COOH}$ group (Stevenson, 1994)(STEVENSON, 1994).

In the $1660 \mathrm{~cm}^{-1}$ region the intensification of the characteristic carbon-carbon unsaturation band, ascribed to the $\mathrm{C}=\mathrm{C}$ stretching of the aromatic ring, can be observed for the aromatic ring vibrations of carbon-carbon unsaturation together with $\mathrm{C}=\mathrm{O}$ and/or $\mathrm{COO}$, indicating the condensation of the carbonic chains (Campos; Ressetti; Zittel, 2014) (Campos; Ressetti; Zittel, 2014). 
The quinones attached to carboxylates and ketones presented intensification in the band near $1508 \mathrm{~cm}^{-1}$, which indicates the elongation of carbon-carbon from aromatic groups (Droussia et al., 2009).

The increase in $\mathrm{C}$ of aromatic and the decrease in $\mathrm{C}$ of aliphatic chains are considered indicators of increased organic matter degradation. For the composting process, these changes may be associated with the stability and maturity of the composts with their highly humified substrate transformations (Droussia et al., 2009).

Recent work on composting in reactors has demonstrated the use of FTIR, which presents absorption peaks, indicating organic matter transformation and formation of mature compounds, characterizing the increase in humic acids during the process (Fels et al., 2014; Campos et al., 2017; Zittel et al., 2018).

The results presented in the FTIR evidenced that the two reactors had the same effect, but there was no difference in the intensity of the peaks. Both reactors indicated that tobacco degradation mixed with DOW and WC occurred. The evaluation of a large volume of waste improved the process with higher organic matter degradation and formation of humified compost.

\subsection{Germination Index GI}

The increase in $\mathrm{GI}$ is attributed to the transformation of toxic compounds such as ammonia, volatile fatty acids, phenolic compounds, among others into mature compounds, free of toxicity (Guo et al., 2012).

For different authors, a GI above 80 indicates maturate compound, free of phytotoxicoses, which can be considered not toxic above 50 (Belo, 2011; Guo et al., 2012; Yang et al., 2016; Wang et al., 2017a). Thus, R1 required 90 days, while $\mathrm{R} 2$ needed 120 days to reach maturity.

Higher proportion of SCT in R2 may have caused the longer time to reach $\mathrm{GI}$, since tobacco is considered toxic, however, some authors argue that $\mathrm{Gl}$ above 50 is already considered to be toxicity free (Zittel et al., 2018).

These results indicate that the degradation of a large amount of tobacco mixed with DOW and WC occurred and therefore can be treated in a reactor system.

\subsection{Heavy metals}

Even SCT presenting high concentrations of toxic metals, the facultative reactor showed efficiency in its treatment, this must be due to the dilution that occurs with the use and mixing of different residues (Fels et al., 2014; Zittel et al., 2018). The results showed that the use of large volumes of SCT in the composting process produced a compost with a concentration below the established limits.

\subsection{Pathogenic microorganisms}

According to the results, the final compound for the two reactors was observed to show absence of pathogens, regarding the studied groups. The absence of pathogens occurred due to temperature variation throughout the process, which remained above $40^{\circ} \mathrm{C}$ for more than five days in the two reactors, besides reaching peaks of $55^{\circ} \mathrm{C}$, temperatures considered by the US.EPA (2003) sufficient for disposal or reduction.
Several mechanisms of pathogenic inactivation are possible, including thermal inactivation, microbial competition, toxicity (produced by the composting process itself, such as ammonia, sulphites, organic acids and phenolic compounds) and enzymatic rupture (Wichuk; Tewari; Mccartney, 2011). The time/temperature relationship is closely linked to the inhibition of growth of these microorganisms or the proliferation thereof and are the most used factors (Jones; Martin, 2003).

\section{CONCLUSION}

Due to the results obtained, residue degradation success was demonstrated for the proposed SWO cigarette mixtures in the two different $\mathrm{C} / \mathrm{N}$ ratios evaluated. The physicochemical and spectroscopic analyzes (UV-Vis and FTIR) showed the stability and maturity of the final compost. And its quality was confirmed by the absence of phytotoxicity (obtained by GI), potentially toxic metals and pathogenic microorganisms.

Therefore, the $2000 \mathrm{~L}$ facultative reactor is a suitable technology for treating large volumes of cigarettes and SWC, and unlike the reports already found in the literature, it has the advantages of having low cost, not attracting vectors, controlling temperature and humidity without the need of management, thus becoming a promising technology for the management of organic solid waste.

\section{REFERENCES}

Abreu, M. J. de. (2017). Compostagem Doméstica, Comunitária e Institucional de Resíduos Orgânicos. Brasília, DF.: Ministério do Meio Ambiente.

ANVISA. Detecção e Identificação de Bactérias de Importância Médica, Pub. L. No. módulo V (2004). Brasil.

Belo, S. R. S. (2011). Avaliação de fitotoxicidade através de Lepidium sativum no âmbito de processos de compostagem. Universidade de Coimbra.

Campos, S. X., Ressetti, R. R., \& Zittel, R. (2014). Monitoring and characterization of compost obtained from household waste and pine sawdust in a facultative reactor by conventional and spectroscopic analysis. Waste Management \& Research, 32(12), 1186-1191.

Campos, S. X. de, Zittel, R., Cunha, K. M. da, \& Colares, L. G. T. (2017). Home composting using facultative reactor. In D. F.-C. Mihai (Ed.), Solid Waste Management in Rural Areas (pp. 103-121). intech.

CCME. (2005). Guidelines for Compost Quality. Canadian Council of Ministers of the Environment.

Chen, Y., Senesi, N., \& Schnitzer, M. (1977). Information provided on humic substances by E4/E6 ratios. Soil Science Society of America Journal.

Chowdhury, A. K. M. M. ., Michailides, M. K., Akratos, C. S., Tekerlekopoulou, A. G., Pavlou, S., \& Vayenas, D. . (2014). Composting of three phase olive mill solid waste using different bulking agents. International Biodeterioration \& Biodegradation, 91, 66-73.

Droussia, Z., D'oraziob, V., Provenzanob, M. R., Hafidic, M., \& Ouatmanea, A. (2009). Study of the biodegradation and transformation of olive-mill residues during composting using FTIR spectroscopy and differential scanning calorimetry. Journal of Hazardous Materials, 164, 1281-1285.

Fels, L. El, Zamama, M., Asli, A. El, \& Hafidi, M. (2014). Assessment of biotransformation of organic matter during co-composting of sewage sludge-lignocelullosic waste by chemical, FTIR analyses, and phytotoxicity tests. International Biodeterioration \& Biodegradation, 87, 128-137.

Feng, P., Weagant, S. D., Grant, M. A., \& Burkhardt, W. Bacteriological Analytical Manual Chapter 4: Enumeration of Escherichia coli and the Coliform Bacteria. (2002). USA. Retrieved from www.fda.gov/\%0AFood/FoodScienceResearch/LaboratoryMethods/ucm064948. htm 
Fialho, L. L., Silva, W. T. L., Milori, D. M. B. P., Simões, M. L., Martin-Neto, L., \& Saab, S. da C. (2010). INTERFERÊNCIA DA LIGNINA NA QUANTIFICAÇÃO DE RADICAIS LIVRES NO PROCESSO DE COMPOSTAGEM. Química Nova, 33(2), 364-369.

Guo, R., Li, G., Jiang, T., Schuchardt, F., Chen, T., Zhao, Y., \& Shen, Y. (2012). Effect of aeration rate, $\mathrm{C} / \mathrm{N}$ ratio and moisture content on the stability and maturity of compost. Bioresource Technology, $112,171-178$.

He, X.-S., Xi, B.-D., Jiang, Y.-H., He, L.-S., Li, D., Pan, H.-W., \& Bai, S.-G. (2013). Structural transformation study of water-extractable organic matter during the industrial composting of cattle manure. Microchemical Journal, 106, 160-166.

Hoffman, W., Pons, J., \& Janer, J. (1934). The sedimentation-concentration method in schistosomiasis mansoni. Public Health Tropical Medicine, 9, 281-298.

IPEA, (Instituto de Pesquisa Econômica Aplicada). (2012). Diagnóstico dos Resíduos Sólidos Urbanos. Brasília, DF.

lyengar, S. R., \& Bhave, P. P. (2006). In-vessel composting of household wastes. Waste Management, 26, 1070-1080.

Jeonga, K.-H., Kim, J. K., Ravindran, B., Lee, D. J., Wong, J. W.-C. S. Kwag, A., ... Jung-Hoon Kwaga. (2017). Evaluation of pilot-scale in-vessel composting for Hanwoo manure management. Bioresource Technology, 245, 201-206.

Jones, P., \& Martin, M. (2003). The occurrence and survival of pathogens of animals and humans in green compost. The Waste and Resources Action Programme.

Karnchanawong, S., \& Suriyanon, N. (2011). Household organic waste composting using bins with different types of passive aeration. Resources, Conservation and Recycling, 55, 548-553.

Khalid, A., Arshad, M., Anjum, M. L., Mahmood, T., \& Dawson, L. (2011). The anaerobic digestion of solid organic waste. Waste Management, 31, 1737-1744.

Kopcic, N., Domanovac, M. V., Kucic, D., \& Briški, F. (2014). Evaluation of laboratory-scale in-vessel co-composting of tobacco and apple waste. Waste Management, 34, 323-328.

MAPA. (2014). Maximum contaminant limits allowed for organic compounds. Retrieved January 1, 2017, from http://www.agricultura. gov.br/assuntos/sustentabilidade/organicos/legislacao/portugues/instrucao-normativa-no-17-de-18-de-junho-de-2014.pdf/ view

Ouaqoudi, F. Z. El, Fels, L. El, Winterton, P., Lemée, L., Amblès, A., \& Hafidi, M. (2014). Study of Humic Acids during Composting of Ligno-Cellulose Waste by Infra-Red Spectroscopic and Thermogravimetric/Thermal Differential Analysis. Compost Science \& Utilization, 22, 188-198.

Oviedo-Ocaña, E. R., Torres-Lozada, P., Marmolejo-Rebellon, L. F., Hoyos, L. V., Gonzales, S., Barrena, R., ... Sanchez, A. (2015). Stability and maturity of biowaste composts derived by small municipalities: Correlation among physical, chemical and biological indices. Waste Management, 43, 63-71.

Pegoraro, A. (2016). Quase 70\% do contrabando que entra no Brasil é de cigarros vindos do Paraguai. Retrieved January 29, 2017, from http://www.folhadomate.com/noticias/policia/quase-70-do-contrabando-que-entra-no-brasil-e-de-cigarros-vindos-do-paraguai
Razaa, S., Munirb, N., Nazb, S., Ahmedb, J., \& Ameen, A. (2017). Effect of $\mathrm{pH}$ During Composting of Municipal Solid Waste. Pakistan Journal of Scientific \& Industrial Research, 60(2), 114-116.

Richard, T. L., Hamelers, H. V. M. (Bert., Veeken, A., \& Silva, T. (2002). Moisture relationships in composting processes. Compost Science \& Utilization, 10(4), 288-302.

Sellami, F., Hachicha, S., Chtourou, M., Medhioub, K., \& Ammar, E. (2008). Maturity assessment of composted olive mill wastes using UV spectra and humification parameters. Bioresource Technology, 99, 6900-6907.

Silva, M. E. F., Lemos, L. T. de, Nunes, O. C., \& Cunha-Queda, A. C. (2014). Influence of the composition of the initial mixtures on the chemical composition, physicochemical properties and humic-like substances content of composts. Waste Management, 34, 21-27.

Stevenson, J. F. (1994). Humus Chemistry (Segunda Ed). WILEy.

US.EPA. (1996). Method 3050B - Acid digestion of sediments, sludges and soils. EPA (ENVIRONMENTAL PROTECTION AGENCY).

US.EPA. (2003). Control of Pathogens and Vector Attraction in Sewage Sludge. United States Environmental Protection Agency. Retrieved from https://www.epa.gov/sites/production/files/2015-07/documents/epa-625-r-92-013.pdf

Wang, S.-P., Zhong, X.-Z., Wang, T.-T., Sun, Z.-Y., Tang, Y.-Q., \& Kida, K (2017). Aerobic composting of distilled grain waste eluted from a Chinese spiritmaking process: The effects of initial pH adjustment. Bioresource Technology, 245, 778-785.

Wang, T.-T., Wang, S.-P., Zhong, X.-Z., Sun, Z.-Y., Huang, Y.-L., Tan, L., ... Kida, K. (2017). Converting digested residue eluted from dry anaerobic digestion of distilled grain waste into value-added fertilizer by aerobic composting. Journal of Cleaner Production, 166, 530-536.

Wichuk, K. M., Tewari, J. P., \& McCartney, D. (2011). Plant Pathogen Eradication During Composting: A Literature Review. Composting Science \& Utilization, 19(3), 244-266.

Wu, C., Wang, Q., Shi, S., Xue, N., Zou, D., Pan, S., \& Liu, S. (2015). Effective utilisation of trickling liquid discharged from a bio-trickling filter as a moisture conditioning agent for composting. Biosystems Engineering, (129), 378 e387.

Xie, S., Hai, F. I., Zhan, X., Guo, W., Ngo, H. H., Price, W. E., \& Nghiem, L. D. (2016). Anaerobic co-digestion: A critical review of mathematical modeling for performance optimization. Bioresource Technology, $222,498-512$

Yang, L., Zhang, S., Chen, Z., Wen, Q., \& Wang, Y. (2016). Maturity and security assessment of pilot-scale aerobic co-composting of penicillin fermentation dregs (PFDs) with sewage sludge. Bioresource Technology, 204, 185-191.

Yen, H.-W., \& Brune, D. E. (2007). Anaerobic co-digestion of algal sludge and waste paper to produce methane. Bioresource Technology, 98(1), 130-134.

Zittel, R., Silva, C. P. da, Domingues, C. E., Stremel, T. R. de O., Almeida T. E., \& Damiani, G. V. (2018). Treatment of smuggled cigarette tobacco by composting process in facultative reactors. Waste Management, $71,115-121$ 